See discussions, stats, and author profiles for this publication at:

https://www.researchgate.net/publication/314213490

\title{
PERSEPSI ISTRI IDEAL DALAM LIRIK LAGU TARLING " ISTRI APA POLISI " KARYA YOYO SUWARYO
}

Conference Paper · September 2016

CITATIONS

0

2 authors:

\section{Bayu Iqbal Anshari \\ Universitas Pendidikan Indonesia 3 PUBLICATIONS 0 CITATIONS \\ SEE PROFILE}

READS

188

Some of the authors of this publication are also working on these related projects: 


\title{
PERSEPSI ISTRI IDEAL DALAM LIRIK LAGU TARLING “ISTRI APA POLISI” KARYA YOYO SUWARYO
}

\author{
Bayu Iqbal Anshari ${ }^{1}$, Moh. Dede ${ }^{2}$ \\ ${ }^{1}$ Departemen Pendidikan Bahasa dan Sastra Indonesia, \\ Universitas Pendidikan Indonesia \\ ${ }^{2}$ Departemen Pendidikan Geografi, \\ Universitas Pendidikan Indonesia
}

\begin{abstract}
Abstrak
Adanya feminisme di era modern, menjadikan sebagian perempuan mampu berperan layaknya seorang laki-laki. Sikap perempuan modern yang pragmatis, tidak jarang terbawa hingga kehidupan bahtera rumah tangga yang dibinanya. Keadaan seperti ini menyebabkan penilaian terhadap peran perempuan dan laki-laki mulai bergeser. Dalam kehidupan rumah tangga modern, peran laki-laki sebagai suami sekaligus kepala rumah tangga acap kali diambil alih oleh perempuan yang berperan sebagai istri dalam urusan menafkahi keluarga. Dalam perspektif masyarakat Pantura Jawa Barat, gambaran akan sosok istri yang ideal tersurat secara jelas dalam tradisi lisan mereka yaitu Tarling. Tarling merupakan seni musik yang berasal dari Cirebon dan Indramayu dengan alat musik utamanya berupa gitar dan suling, sehingga nama Tarling pun merupakan akronim dari dua instrumen musik tersebut. Gambaran perempuan sebagai sosok istri ideal salah satunya terdapat dalam lirik lagu tarling yang berjudul "Istri apa Polisi" karya seniman tarling kondang Yoyo Suwaryo. Metode analisis yang akan digunakan adalah deskriptif kualitatif dengan rumusan masalah yang akan dibahas pada penelitian ini adalah bagaimana gambaran sosok istri ideal dalam lirik lagu tarling "Istri apa Polisi". Dalam lirik lagu tersebut, didapatkan gambaran sosok perempuan ideal menurut masyarakat Pantura Jawa Barat merupakan sosok perempuan yang patuh terhadap suami, selalu mendoakan suaminya, berbakti, sabar, tawakal, beriman, qanaah, selalu husnudzon, dan menghargai suami dengan sepenuh hati.
\end{abstract}

Kata kunci: tarling, sosok istri ideal, Pantura Jawa Barat

\section{PERCEPTION OF IDEAL WIFE IN TARLING LYRIC SONG "ISTRI APA POLISI" FROM YOYO SUWARYO}

\author{
Bayu Iqbal Anshari ${ }^{1}$, Moh. Dede ${ }^{2}$ \\ ${ }^{1}$ Departement of Language and Literature Education, \\ Universitas Pendidikan Indonesia \\ ${ }^{2}$ Departement of Geography Education, \\ Universitas Pendidikan Indonesia
}

\begin{abstract}
The presence of feminism in the modern era, making some women are able to act like a man. A pragmatic attitude of modern women, it is not uncommon to carry into household life. These condition led to roles assessment of women and men
\end{abstract}


began to shift. In modern household life, the male role as a husband and as the head of the household are often taken over by a woman who plays the wife in matters provide for the family. In the perspective of Pantura West Java society, an overview will be the ideal wife figure clearly expressed in their oral tradition like Tarling. Tarling is a musical art from Cirebon and Indramayu with the main musical instrument in the form of gitar (guitar) and suling (flute), so Tarling is acronym of the two musical instruments. Image of women as ideal wife figure are contained in the song lyrics Tarling entitled "Istri apa Polisi“" (Wife of Police) work of famous artist Tarling Yoyo Suwaryo. The analytical method used is a qualitative descriptive with formulation of the problem to be addressed in this study is how the image of an ideal wife figure in the lyrics Tarling "Istri apa Polisi". In this lyrics, ideal woman figure in society of Pantura West Java is a woman figure who is obedient to her husband, always pray for her husband, dutiful, patient, trust, faith, qanaah (optimistic), always husnudzon (positive think), and appreciate the husband with all heart.

Keywords: Tarling, ideal wife figure, Pantura West Java

\section{A. Pendahuluan}

Feminisme berupaya mewujudkan persamaan hak bagi perempuan terhadap laki-laki (Humm, 2007). Fenomena tersebut menimbulkan berbagai permasalahan sosial yang kompleks seperti perceraian dan kekerasan hingga disorganisasi keluarga, yaitu perpecahan keluarga sebagai suatu unit karena anggota-anggotanya gagal memenuhi kewajiban-kewajibannya yang sesuai dengan peranan sosialnya (Soekanto dan Sulistyowati, 2013).

Feminisme global, turut pula mempengaruhi pola pikir masyarakat Pantura Jawa Barat dan menciptakan berbagai masalah seperti intensitas perceraian di Pantura Jawa Barat merupakan yang tertinggi di Indonesia (Budiman, 2015). Selain itu, Feminisme di Pantura Jawa Barat menimbulkan pergeseran peran antara lakilaki dan perempuan dalam keluarga. Melihat kondisi tersebut, Yoyo Suwaryo menuangkan gagasannya dalam bentuk lagu Tarling berjudul "Istri apa Polisi".

Tujuan penelitian ini untuk menggambarkan sosok istri ideal melalui perspektif masyarakat Pantura Jawa Barat yang mencakup wilayah Cirebon, Indramayu dan sekitarnya baik dari sikap maupun peran atau tindakan istri guna menciptakan kebahagiaan di lingkungan keluarga yang didasari atas nilai-nilai kebudayaan setempat, seperti yang terkandung pada lagu Tarling yang berjudul "Istri apa Polisi”.

Teori yang sejalan dengan tujuan di atas adalah teori Ferdinand de Saussure (1959) yang mengatakan bahwa sistem petanda dan penanda merpakan wujud korelasi antara budaya dan bahasa. Rumusan masalah yang akan dibahas pada penelitian ini adalah bagaimana gambaran sosok istri ideal pada masyarakat Pantura 
Jawa Barat dalam lirik lagu tarling "Istri apa Polisi". Sedangkan, metode penelitian yang digunakan adalah metode deskriptif kualitatif. Dalam penelitian ini, instrumen penelitian berupa manusia atau human instrument, dengan menjadikan peneliti sebagai instrumen kunci (Sugiyono, 2008).

\section{B. Hasil dan Pembahasan}

Berdasarkan hasil transkrip terhadap lagu tarling "Istri apa Polisi" karangan alm. Yoyo Suwaryo diperoleh data berupa lirik lagu dalam bahasa Cirebon yang kemudian ditransliterasi ke dalam bahasa Indonesia dengan berpedoman pada Kamus Bahasa Cirebon yang disusun oleh Sudjana (2001), selanjutnya lirik lagu tersebut akan dianalisis struktur teksnya. Untuk lebih jelasnya, pada Tabel 1 ditampilkan teks lirik "Istri apa Polisi” beserta terjemahannya.

Tabel 1 Lirik dan Terjemahan

\begin{tabular}{|c|c|}
\hline Lirik asli (basa cirebon) & Terjemahan \\
\hline \multicolumn{2}{|c|}{ Bait 1} \\
\hline Yen emong tukar, & Jika tidak ingin bertengkar, \\
\hline Dadi ya wadon sing sabar & Jadilah perempuan yang sabar \\
\hline Yen arep nurut, & Jika ingin patuh, \\
\hline Tulung aja prengat-prengut & Mohon jangan cemberut \\
\hline \multicolumn{2}{|c|}{ Bait 2} \\
\hline Kita wong lanang, & Saya sebagai suami, \\
\hline Tanggung jawab masa depan & Penanggung jawab masa depan \\
\hline Anak lan rabi, & Anak dan istri, \\
\hline Arep sapa sing ngurusi? & Siapa yang akan menafkahi? \\
\hline \multicolumn{2}{|c|}{ Bait 3} \\
\hline Wadon kang iman, & Perempuan beriman, \\
\hline Dudu karena kudungan & Bukan (hanya) karena jilbabnya \\
\hline Nrima kenyataan, & Menerima kenyataan, \\
\hline Enak blenak takdir tuhan & Susah senang takdir tuhan \\
\hline \multicolumn{2}{|c|}{ Bait 4} \\
\hline $\begin{array}{l}\text { Wong lanang usaha, wadon } \\
\text { dedonga }\end{array}$ & $\begin{array}{l}\text { Suami mencari nafkah, istri } \\
\text { berdoa }\end{array}$ \\
\hline Aja sewot lan salah sangka & Jangan marah apalagi curiga \\
\hline $\begin{array}{l}\text { Sang istri tugase mbakti ning } \\
\text { laki }\end{array}$ & Sang istri berbakti pada suami \\
\hline Lawang sorga uwis ngenteni & Pintu surga sudah menanti \\
\hline \multicolumn{2}{|c|}{ Bait 5} \\
\hline
\end{tabular}


Seminar Internasional Riksa Bahasa X Literasi dan Budaya Bangsa

Bandung, 2016

(C) Prodi Pendidikan Bahasa Indonesia, Sekolah Pascasarjana Universitas, UPI

\begin{tabular}{l|l}
\hline Yen sira ora percaya & Jika tidak percaya \\
\hline Takon ning bapak kiyai & Bertanyalah pada pak kyai \\
\hline Sejen karo polisi & Berbeda dengan polisi \\
\hline Kuwen lagi... & Mereka sedang... \\
\hline $\begin{array}{l}\text { Ngejar prestasi luruh barang } \\
\text { bukti }\end{array}$ & $\begin{array}{l}\text { Mengejar prestasi mencari } \\
\text { barang bukti }\end{array}$ \\
\hline
\end{tabular}

Dalam lagu "Istri apa Polisi" terdapat keteraturan pada akhir lariknya. Bisa dilihat pada akhir larik terdapat rima a-a-b-b (bait 1, 2, dan 4), a-a-a-a (bait 3), dan a-b-b-b (bait 5). Selain itu, sebagian besar lariknya berbentuk pernyataan dan hanya ada satu lirik yang bebbentuk pertanyaan.

\section{Gambaran sosok istri ideal dalam lirik lagu "Istri apa Polisi"}

Berdasarkan lirik lagu "Istri apa Polisi" didapatkan gambaran sikap yang diidamkan oleh masayarakat Pantura Jawa Barat mengenai istri ideal yang didasarkan atas struktur kalimat yang terdapat pada tiap larik yang menunjukan sikap.

Dalam lagu Tarling "Istri apa Polisi" terdapat lirik yang menggambarkan salah satu sikap yang istri yang ideal, yaitu Yen arep nurut, tulung aja prengatprengut. Lirik tersebut menandakan istri yang harus patuh dan ikhlas melayani suaminya. Karena, kata prengat-prengut dalam lirik ini menandakan sikap yang bertentangan dengan sikap patuh dan ikhlas.

Selanjutnya, lirik lain yang menggambarkan istri ideal adalah Wadon kang iman, dudu karena kudungan. Pada lirik tersebut mengandung makna bahwa perempuan yang berkerudung belum tentu beriman. Karena seseorang disebut beriman bukan hanya oleh satu aspek tetapi ada banyak hal yang bisa membuat seseorang beriman.

Pada lirik berikutnya, Nrima kenyataan, enak blenak takdir Tuhan, lirik tersebut menjelaskan secara eksplisit bahwa salah satu impian dari laki-laki di Pantura Jawa Barat adalah istri yang tawakal. Dengan sifat tawakal, seorang istri akan menerima apapun kelebihan dan kekurangan yang dimiliki oleh pasangannya.

Wong lanang usaha, wadon dedonga terdapat pada bait keempat baris pertama. Baris ini memuat kalimat Wong lanang usaha yang memiliki makna lakilaki sedang berusaha, terdapat kata Wadon dedonga memiliki makna bukan sekedar berdoa, tetapi mendukung penuh segala usaha baik suami dalam mencari nafkah. Sehingga memacu tanggung jawab dan komitmen yang tinggi dari suami (Hanum, 2010).

Baris selanjutnya memuat kalimat Aja sewot lan salah sangka. Kata aja sewot lan salah sangka atau suudzan dalam budaya Pantura Jawa Barat menunjukan kecemburuan tinggi oleh istri terhadap suami. Kondisi demikian memang tak bisa dilepaskan dari fenomena wong lanang tukmis dan adanya 
dongbret di wilayah Pantura Jawa Barat. Apabila sikap suudzan terus terjadi akan berdampak pada pola komunikasi interpersonal antara suami dan istri menjadi tidak efektif (Tailor dalam Rakhmat, 1996).

Sang istri tugase mbakti ning laki merupakan kelanjutan dari baris sebelumnya. Dalam kehidupan sosial, masyarakat Pantura Jawa Barat menghadirkan sosok perempuan tangguh. Bahkan, superposisi laki-laki bisa saja tergerus akibat peran perempuan yang semakin kuat di dalam keluarga sebagai dampak feminisasi (Henslin, 2007).

Yen sira ora percaya takon ning bapak kiyai, sejan karo polisi merupakan salah satu lirik yang menunjukan bahwa agama memiliki pengaruh yang kuat bagi masyarakat Pantura Jawa Barat. Menurut Horikashi (1976) Ulama dijadikan panutan sekaligus agen kontrol sosial,. Lirik ini juga melambangkan bahwa, istri diberikan hak untuk menanyakan urusan agama dan sosial sekaligus cerminan kepercayaan masyarakat terhadap polisi di wilayah ini.

\section{Simpulan}

Tarling merupakan salah satu tradisi lisan yang berfungsi sebagai wahana penyampaian gagasan yang mampu diterima luas sebagai kesenian. Tarling bersandar dari kebudayaan masyarakat Pantura Jawa Barat yang dinamis dan kompleks. Yoyo Suwaryo menciptakan lagu Tarling "Istri apa Polisi" untuk menggambarkan sosok istri ideal dengan perspektif masyarakat Pantura Jawa Barat. Sosok istri yang diidamkan oleh laki-laki di sana adalah sosok perempuan yang patuh terhadap suami, selalu mendoakan suaminya, berbakti, sabar, tawakal, beriman, qanaah, selalu husnudzon, dan menghargai suami dengan sepenuh hati.

\section{DAFTAR PUSTAKA}

Budiman, A.. (2016). Kasus Cerai Indramayu Tertinggi di Indonesia. Tersedia [daring]. http://www.pikiran-rakyat.com/jawa-barat/2016/03/15/364250/kasuscerai-indramayu-tertinggi-di-indonesia . Diakses 14 juli 2016.

Hanum, F.. (2010). Peran Istri Dalam Memotivasi Prestasi Kerja Suami. Makalah Perkebunan Sawit Balikpapan Kaltim. Balikpapan: Tidak Diterbitkan.

Henslin, J.M.. (2007). Essentials of Sociology: a Down to Earth Approach. Terjemahan. Jakarta: Erlangga.

Horikashi, H.. (1976). A Traditional Leader in a Time of Change the Kiai and Ulama in West Java. Urbana: Univeristy of Illinois.

Humm, M.. (2007). Ensiklopedia-Feminisme.Yogyakarta: Fajar Pustaka Baru.

Rakhmat, J. (1996). Psikologi komunikasi. Bandung: PT Remaja Rosdakarya.

Saussure, F. (1959). Course in General Linguistics. New York: Philosophical Lib.

Soekanto, S. dan B. Sulistiawati. (2013). Sosiologi Suatu Pengantar. Jakarta: Raja Grafindo Persada.

Sudjana, T.D.. (2001). Kamus Bahasa Cirebon. Bandung: Humaniora Utama Press. 
Seminar Internasional Riksa Bahasa X Literasi dan Budaya Bangsa

Bandung, 2016

(C) Prodi Pendidikan Bahasa Indonesia, Sekolah Pascasarjana Universitas, UPI

Sugiyono. (2008). Metode Penelitian Kuantitatif, Kualitatif, dan R\&D. Bandung: Alfabeta.

\section{Biodata Penulis}

$\begin{array}{ll}\text { Nama } & : \text { Bayu Iqbal Anshari } \\ \text { Afiliasi } & \begin{array}{l}: \text { Universitas Pendidikan Indonesia, Departemen Pendidikan } \\ \text { Bahasa dan Sastra Indonesia }\end{array} \\ & \text { Jalan Setiabudhi No. 229, Bandung } \\ \text { Nomor Telepon } & : \text { 089510563013 } \\ \text { Pos-el } & \text { bayuiqbal36@ student.upi.edu } \\ \text { Nama } & : \text { Moh. Dede } \\ \text { Afiliasi } & \begin{array}{l}\text { : Universitas Pendidikan Indonesia, Departemen Pendidikan } \\ \text { Geografi }\end{array} \\ & \text { Jalan Setiabudhi No. 229, Bandung } \\ \text { Nomor Telepon } & : \text { 085223295937 } \\ \text { Pos-el } & : \text { desa96@ student.upi.edu }\end{array}$

